Article

\title{
The Media Protest of Neighbouring Associations, Promoter of Citizen Democratic Culture during Transition in Southern Spain
}

\author{
Sandra Méndez-Muros \\ Department of Journalism II, University of Seville, 41092 Seville, Spain; E-Mail: sanmenmur@us.es
}

Submitted: 29 September 2017 | Accepted: 6 December 2017 | Published: 9 February 2018

\begin{abstract}
In the current context of placing value on the neighbouring movement within the Spanish democratic Transition, we set out to confirm that the press actively participates in the growing conjunction of neighbouring issues with political content and contributes to the idea that this movement becomes a parameter of the democratic culture for the citizen during Transition. Since the conflict is newsworthy, we conduct a micro-social study of the neighbouring protest in the newspaper El Correo de Andalucía, published in the southern Spanish city of Seville. Through analysis of content, we study the informative flow and the repertoire of protest following a typology that distinguishes four formats (demonstrations, strikes, speeches and associations) divided into two levels of conflict. The analysis sample consists of 33 texts published between November 1975 (Franco's death and the accession to the throne of Juan Carlos I) and June 1977 (the first democratic general elections). The main conclusion reveals that the newspaper becomes a platform that gives visibility to the neighbouring movement, normalising behaviours and procedure rules through the protest.
\end{abstract}

\section{Keywords}

civil society; democratic culture; local press; media; media history; neighbouring movement; Spanish Transition

\section{Issue}

This article is part of the issue "Media History and Democracy", edited by David W. Park (Lake Forest College, USA).

(C) 2018 by the author; licensee Cogitatio (Lisbon, Portugal). This article is licensed under a Creative Commons Attribution 4.0 International License (CC BY).

\section{Introduction}

In Spain, the resurgence of the civil society in the seventies of the twentieth century acquires particular connotations when counting the democratic Transition as a backdrop, with the desire for freedom and solutions to numerous social and economic problems. In this context, the neighbouring movement emerges with a strongly demanding attitude towards issues related to health, public services, housing, education, etc., along with the request for a democratic political change which places it on a local-global axis (Pérez Quintana \& Sánchez, 2008, p. 15) as a powerful pressure motor.

The neighbouring protest of recent years is not an exclusively Spanish phenomenon. Italian cities such as Rome, Milan or Turin also experience a demanding process propelled by the accelerated urban development and ineptitude of the ruling political class to apply reforms capable of solving or mitigating the problems
(Alonso, 2011, p. 58; Lowe, 1986, pp. 183-185). The same could be said about France, Portugal (Ramos Pinto, 2005) or Mexico (Borja, 1986, p. 40).

The peculiarity in the Spanish case lies in the fact that the local movement is born within a broader cycle of protest which advocates a political change which conditions the contents of its demands, its organisational structure and its forms of internal and external action (assemblies, direct vote, demonstrations, citizen participation, discussions, traffic cut-offs, etc.) (Sánchez, 2011, p. 104). We can find other differences in which foreign administrations are more efficient and responsive to social demands and, in addition, that trade unions and parties assume them as their own (Angulo, 1978, p. 156).

Since the first decades of the twenty-first century, the neighbouring movement in the public space of the street has been progressively taken into consideration with its own entity and essential contribution for democratic awareness. Until then, despite being defined as 
"the most widespread and significant urban movement in Europe since 1945" by sociologist Manuel Castells (1986, p. 299), for decades the Spanish neighbouring movement has been one of the great laggards among the contributions that explain the history of Spanish democratisation. The reasons for their lesser visibility are general, connected with the role of civil society as a whole during Transition and the preponderance of other movements such as the worker or the student, and are concrete, regarding their blurring in interests of other groups, especially political parties.

Contreras (2012, p. 112) argues that the study of the neighbouring movement in Andalusia is far from making new contributions within the narrative published about Transition due to several reasons: 1 ) the late study of urban social protest beyond the labour and student movement; 2 ) the documentary losses suffered by the neighbouring associations themselves at their headquarters; 3) legal impediments to the documentation query on the neighbouring movement in historical and intermediate archives as well as in official records; and 4) the biological disappearance of some of the protagonists who may be interviewed.

Although historiography and sociology have been in charge of studying the role of the neighbouring movement in the street, there has not been any in-depth study on the media message about the local movement when the analysis of its forms, contents, and languages may become not only a documentary source to obtain historical data, but also a tool to complete the reasons concerning the lower visibility of the movement as a part of the process of democratic culture of local citizenship, within the recent Andalusian historiographic vision.

\section{Literature Review}

\subsection{Civil Society and Protest Movements in Transition}

Franco's dictatorship has ruined most of the framework of progressive civic, cultural, and political popular associations through prohibitions and controls. The tradition of democratic participation is broken with the consequent lack of opportunity of the generations born during Franco's regime to socialise (Institut D'Anàlisi i Social Politiques Pùbliques \& Fundaciò Francesc Ferrer I Guàrdia, 2000, p. 205), but it cannot be avoided, since the 1950 s of the twentieth century, workers, clandestine political opposition, students, and intellectuals have been organised, given that the dissent is greater than that allowed by the Collective Labour Agreements Act of 24 April 1958 and the Associations Act of 24 December 1964, although there is consent "to persons linked to anti-Francoism to open spaces of freedom that are independent of Franco's officialdom space" (Ferrer, 2014, pp. 83-84). This law brings about the appearance of associations of family heads and housewives in Spain, mainly in the peripheral quarters within the framework of the National Movement as the first step of urban social movement. Other formulas were the municipal collaborating councils, the municipal district councils, the neighbouring communities, and the quarter mayoralties.

In the 1960s, there was a resurgence of social and labour dispute due to economic transformations and, with it, the emergence of a protest movement which proved to be better prepared than the state to solve social problems (Pérez Díaz, 1996, p. 19), in the line posed by Musil $(2013$, p. 24$)$ where he states that the opposition to Francoism practices its citizenship before becoming a citizen into a democratic system, imposing and practising democratic rights such as freedom of press, opinion, assembly, and association. Until the second half of the 1970s the protest adopted different and multiple formulas (demonstrations, work-ins, sit-ins, work placements, strikes) (Ortega, 2004, pp. 351-370).

From a historical and sociological point of view, there is still no consensus on the civil society's role during the democratic Transition. Theories maintaining that the political change engine is the civil society argue that Transition: 1 ) is the result of civil society's role which is involved in mobilisations and fights for freedoms and rights within the citizen's resurgence (Pérez Díaz, 1987; Threlfall, 2008) or 2) is a "bottom-up" phenomenon for two decades before the process and "top-down" in the process itself (Musil, 2013, p. 11). Moreover, the theories that support that civil society's role is not essential in the process of change, believe that Transition is: 1 ) the result of the political and economic liberalisation of Franco's regime during the 1960 ; 2 ) an action taken "from above" (García, 1981, pp. 89, 103) by the political class given the social demobilisation, or 3 ) the readaptation of the dominant classes of democracy in order to maintain its hegemony (Giner \& Sevilla, 1980, pp. 197-229). In this line, Salgado (2014, pp. 271-295) recognises the social movements' role although they are not decisive to stimulate a change in the political system.

All the aforementioned arguments lead those authors who consider that civil society plays a fundamental role in Transition to the study of varied movements (political opposition, students, workers, cultural current), among which the neighbouring movement is not predominant. Over these past few years, a match with other movements has been recognised. Martínez i Muntada (2008, p. 2333) asserts that the neighbouring movement, on par with the labour movement, is one of the most important scopes of participation and mobilisation coming from relatively large sectors of the population during the last years of Franco and Transition in the main urban centres.

The neighbouring associations and the neighbouring movement in general have been recognised as an influence in the building of local democracy, becoming "the first step in the participation of many citizens" (Serrano \& Sempere, 1999, p. 176), who learned and developed a democratic culture from the closest scope using their real experience. Furthermore, the neighbouring associations become "schools of democracy and citizenship, 
teaching their associates how to relate to administration, participation methods and procedures to choose leaders" (Contreras, 2012, p. 113). Fernandes (2014) also indicates that the revolutionary pathways towards democracy in Portugal and Spain have a positive impact on the self-organising capabilities of popular groups.

Most of the studies on neighbouring associations in Spain during the Transition have a historical nature agree that their emergence is due to the lack of representativeness of local institutions and conclude that these associations play a crucial role in the achievement of a democratic political change. Some of them focus on its placement value in the Spanish context (Bordetas, 2014) or by regions, such as Andalusia, studied by Contreras (2013) and Escaleras and Ruiz (2006), and the cities of Madrid and Barcelona (Gail, 1979) or Zaragoza (Gómez Bahillo, 2006). In these studies, the actions of neighbouring movements, socio-economic-cultural differences/similarities or common points with other movements are analysed from a descriptive perspective.

Something similar has happened with studies in other countries. In Germany, Althaus (2000) studies the development of neighbouring communities at the end of the Second World War as a timely emergency that assumed tasks of the local government under construction; in Italy, Alonso (2011) analyses these movements in Rome between 1968 and 1976, observing their structures, demands, and forms of action; in Venezuela and Colombia, Ramos Rollón (1995) conducts a comparative field study between the cities of Bogotá and Caracas; in Argentina, Oraisón (2011) studies the difficulties of these types of communities to be recognised and legitimised through institutionalisation; in Mexico, Frutos (2002) studies how in 1988 the autonomous neighbouring organizations in the Federal District tried to save their traditions and spaces of coexistence that rejected the narrow legal frameworks of political participation, and Safa (1998) analyses the factors that take part in the neighbouring construction in the Federal District. Bultmann, Hellmann, Maschkat and Rojas (1995) showed interested in the neighbouring associations in Mexico and Chile and their democratization process, studying the behaviour of actors and movements.

We only find recent studies that address the role of neighbouring associations from a communicative point of view in more recent years, such as the one conducted by Gonzalo (2015), who approaches the neighbouring movement of Valladolid from the interview method during the Transition in the press used as a source for History. Outside Spain, Carrasco (2011) analyses the role of communication in a local citizen participation process in a district of Lima, Peru.

\subsection{The Newspaper as an Interest Mediator}

Any citizen action is essentially expressed in two spaces: the street and the media. Democratic interaction functions through the promotion of interests, and these are usually settled in the media (Luna, 2003, p. 31). As spaces of freedom arise, the media assimilate information from civil society (associations, societies, groups, interest groups, personalities, etc.) and transform and transmit to political power a complex image of society with its contradictions, demands, and requirements. The newspaper exerts a mediating function by relating these demands, especially in unsolved problems, regarding the social environment and decision making by the political system, as well as stimulating citizens towards participation in social life and contributing to general stability (Gomis, 1987, pp. 308-310).

The press facilitates the coexistence and social integration in any socialisation process by showing the neighbour codes, attitudes, values, dominant ideas, visions, expectations, objectives, etc. of other citizens who appear in the media. The neighbour then recognises his social ego through metonymic action by identifying with and facing these various aspects. In this sense, the neighbouring movement gets the media to provide "a growing coverage and expression which becomes a real sounding board for local actions" (Lander, 2006, p. 49) and, ultimately, the newspaper becomes a media source for democratic culture.

The press contributed to the spreading of democratic ideology much more than most political groups (Tusell, 1989, p. 203). Although, both Zugasti $(2007$, p. 69, 2008, pp. 53-68), when analysing the Madrid press and speaking about "media accommodation", as well as Montero, Rodríguez and García (2008, pp. 293-296, 307), in their study of the Madrid, Catalan, and Basque newspapers, reach similar conclusions on the voluntary collaboration of journalism with the democratising objectives of political power, though the latter refer that this collaboration is not based on an official agreement or an explicit deal to facilitate consensus.

The development of civil society in the Spanish case is inextricably linked to the media, especially encouraged by the promulgation of the Press and Printing Law $14 / 1966$, through which newspapers can inform regarding the institutionalisation of the State, the role of the National Movement in Spanish life, political associations, Monarchy, the Church, the trade union setting, as well as problematic areas of Spanish life: university disorders, labour conflicts, regionalisms, etc. which make the idyllic image of a Spain without problems disappear (Barrera, 1995b, p. 19).

This law, which was in force to a great extent until the promulgation of the Constitution of 1978 where in its article 20 , the freedom of expression was fully recognised not only for the journalistic union but for all Spanish citizens, it suppressed the previous censorship, but the editors could check with the ministry in order to publish certain news and opinions in order to avoid administrative records, which could be called self-censorship. Furthermore, the warning cries to the editors continued through personal or telephone conversations. Between 1966 and 1975, 1,270 cases were opened, as well as sanc- 
tions (fines, suspensions, confiscations, pressures) and threats of professional disqualification to editors that, in some cases, included arrest and prosecution before the Public Order Court (Barrera, 1995a, p. 106). During these years, a journalist could be judged by six different court categories, including the military.

This did not prevent the growth of the newspaper market and the appearance of new magazines and newspapers. At the national level, new publications reached the number of 129; the circulation of newspapers reached two and a half million in 1967, and 915 publishing houses in 1971, and Spain reached fifth place in the world in number of published titles (Sinova, 1989, p. 267; Tusell, 1989, pp. 190-191).

Until the publication of the Royal Decree-Law 24/1977 on Freedom of Expression, which was created under the Law for Political Reform, the administrative seizure of publications was not partially suppressed, the controversial article 2 was repealed by which freedom of expression was submitted to the Principles of the National Movement and there was a register of journalists and journalistic companies and the previous deposit of copies to be examined and, just in case, allow the seizure of publications.

With all this, an atmosphere of greater freedom of expression was perceived in all social orders and this was reflected in the press: new sections, interpreting journalistic genres, unofficial information, citizen sources, etc. However, the editors had to continue responding to crimes committed by third parties and the accumulation of three files in one year led automatically to their inability to continue conducting their duties, and some aggressions persisted: the Public Order Court continued to act against the press; there were military processes, farces to discredit newspapers, and pressures applied to companies.

\section{Methodology}

This work aims at confirming that the press actively participates in the growing conjunction of neighbouring issues with political content in its information and contributes to the idea that the neighbouring movement becomes a parameter of democratic culture for the Sevillians during the democratic Transition. According to Héctor Borrat's (1989, pp. 28-29) classification regarding the role of the newspaper in social conflicts, we start from the idea that the newspaper goes through a three-level process: extra level (external observer), inter level (neutral intermediary in conflict relations) and intra level (collective actor involved in internal conflicts).

We conducted a micro-social study of Seville's neighbouring protest in the newspaper El Correo de Andalucia - the real geographic coverage makes it a local newspaper in Seville-bearing in mind that the conflict is always newsworthy and that national power is prolonged in every Spanish city without exceptions, which is the reason why Transition to democracy in Andalusia does not differ at all from that of the remaining Spanish territory (Gómez \& González, 2000, p. 468; Pérez Quintana \& Sánchez, 2008; Vilà, 2016).

El Correo de Andalucía was not the most read newspaper in the study period. In 1976-1977, it had a print run of 35,559 copies and a dissemination of 31,249 readers (Pérez Vilariño, 1982, p. 68), while Abc de Sevilla, which was the most widely-read newspaper, had a print run of 61,180 copies and a dissemination of 54,259 readers in the same period (Iglesias, 1980, p. 453). However, it became an anti-Franco emblem that earned him the progressive press profile and the qualification of "red scourge" (De Pablos, 1981, p. 40) since the 1960s.

In 1975, the newspaper left behind its most rebellious period with the two Catholic editors of the progressive lustrum (1967-1971), in which the newspaper hosted topics and principals belonging to social sectors that were not heard in other city media: university students, workers, priests, exiles and political prisoners, trade unionists, among others, with the common idea of their frontal positioning to Franco's regime. This earned the newspaper a multitude of sanctions and kidnappings. The newspaper became one of the most uncomfortable for Franco's regime and one of the twenty Spanish publications that suffered the greatest number of files (Fuentes \& Fernández, 1998, p. 298). These two editors accumulated a total of 27 disciplinary actions in five years.

After the passage of the Editorial Católica (19721973) to its shareholders, when there was a decline in the struggle for freedom, the newspaper again tried to make use of the right of information. In 1974, the newspaper conducted the first interview in Spain with Felipe González, then general secretary of the Spanish Socialist Workers Party in hiding, which led to his arrest and also the interviewer's. The new editor accumulated new files, fines, temporary suspensions and jail requests, as a result of the repression by the Ministry of Information in the last months of the dictatorship against the most critical publications. During the Transition, the then editor was also the target of telephone threats, fines, and visits to the court, in addition to the censorship regarding information about the visit of monarchs Juan Carlos and Sofia to Seville in March 1976. This did not sway the correspondent team and it was granted the distinction of "Sevillians of the year 1975" in 1976 for being "tireless spokesmen of the most grieving echoes" of the province and promoting colloquiums for dialogue and the national coexistence during the Transition years.

The analysis sample consists of 33 texts (news, declarations, conferences, interviews, and reports) related exclusively to the stream of residents' demands and not those that deal with the decisions made by the municipal political power, which would mean more texts, during 10 two-month periods, which correspond to $100 \%$ of the texts published on the subject. The newspaper selection was carried out with copies of El Correo de Andalucía, located in the Municipal Newspaper Library of 
Seville. We are facing a single media due to its very representative trajectory. We understand that by the own ideological character of the newspaper, it would publish all the demands conducted by the neighbouring associations, which are much less numerous than those originated in worker or student scopes. Moreover, we must bear in mind that no newspaper is a faithful mirror of reality because in its production subjective factors take part in the selection and hierarchy of information.

Through the content analysis (Bardin, 1996, p. 80), we analyse the information flow from the quantitative aspect to measure the evolution during the study period (see Figure 1) and, from a qualitative point of view, we observe the formats of the protest repertoire (see Figure 2), following Méndez-Muros's typology (2013, p. 74). The journalistic texts have been classified based on the four repertoire formats that are as follows: demonstrations, strikes, speeches, and associations. In our case, we focus on three out of the four formats, since the neighbouring protest does not contemplate strikes. The protest formats fall into two levels of conflict: level 1, or high (demonstrations and strikes) and level 2, or low (speeches and associations), according to the public order problems generated and the consequent image of the neighbouring struggle for the democratic rights of the reader. The conflict modulation throughout the analysis period expresses the assumption degree of these democratic values in society which is perceived by citizens as the normalisation of protest. The presentation of the results follows a chronological and diachronic thread in the event progress and is divided into three stages between November 1975 (Franco's death and the accession to the throne of Juan Carlos I) and June 1977 (celebration of the first democratic general elections).

\section{Results: The Neighbouring Associations of Seville as a Case Study}

\subsection{The Awakening of the Neighbouring and Democratic Consciousness}

Since the death of Franco until the end of 1975, El Correo de Andalucía (hereinafter, ECA) does not publish texts related to the neighbouring protest; in 1976 the newspaper accumulates the highest recorded data in the whole analysis period with $69.6 \%$, which natural taking into account that this is the longest time period, while in the months analysed in 1977, the remaining $30.3 \%$ is concentrated. Generally speaking, protest formats used by the neighbouring movement are as follows: demonstrations (48.4\%), speeches (33.3\%), and associations (18.1\%), and the four fundamental thematic axes are based on: 1) the lack of housing, 2) the need for minimum services and infrastructures, 3) disagreement with some public works, and 4) political demands as a direct consequence of the intensification of structural imbalances in the process of political and social transformation.

In January-February of 1976, the protest covers $12.1 \%$ of the total, the lack of housing being the main focus. It is a protest expressed mainly through speeches $(50 \%)$, because the texts dealing with associations and demonstrations encompass the remaining percentage in equal parts. Therefore, the requests of the Association of family heads San Jerónimo revolve around the insufficiency of the works being exercised, the execution in the quarter La Tercia, and a photograph of the affected area of the news "The running construction work in the quarter La Tercia is considered insufficient" is exposed (ECA, 1976a, left central page).

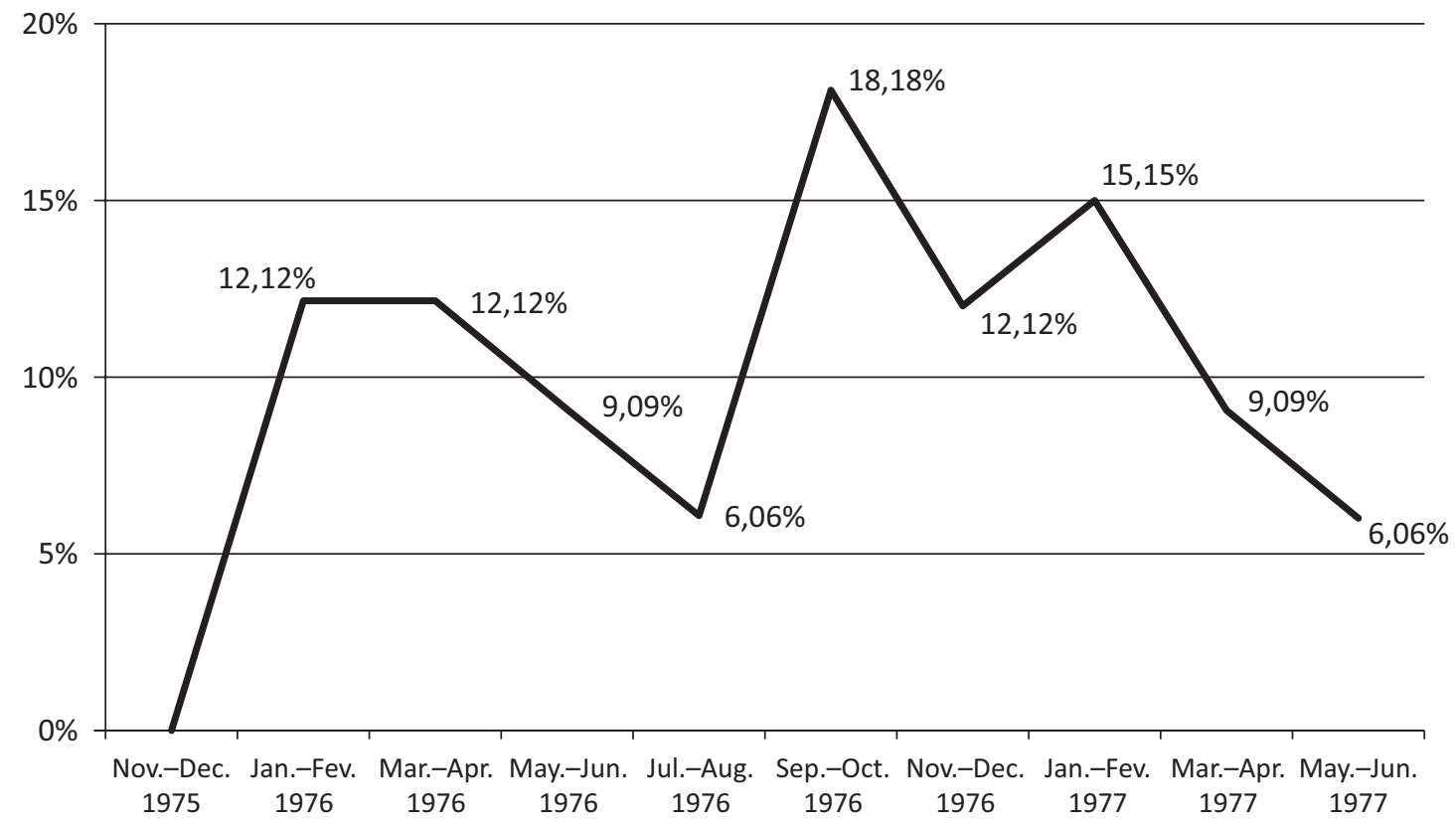

Figure 1. Evolution of the neighbouring protest in ECA (1975-1977). 
The political factor soon appears and the newspaper is not indifferent to the implicit political dimension. From the beginning of Transition, the residents of some quarters present evident demands of amnesty such as the one shown in the piece "Residents of five neighbourhoods request amnesty" (ECA, 1976b, p. 20). The same happens with the authorisation or denial of the demonstration permission. The lack of services is behind the demonstrations of neighbours that are carried out illegally in the San Diego quarter by the electric power cutoff as reported in the article "Demonstration of neighbours with lit candles" (ECA, 1976c, p. 19).

The protest percentage $(12.1 \%)$ is maintained in March and April, although speeches (25\%) give way to associations (50\%), while demonstrations cover the rest. The lack of services is present in news such as a meeting of the residents of the Palmete quarter to solve their problems of sewerage, lighting, water, etc. ("Palmete's residents insist", ECA, 1976d, p. 15), but social problems are increasingly linked to the political situation, as seen in a piece of news which equates national and local problems:

A thousand people concentrated on the esplanade of the Nuestra Señora del Pilar church at about eight o'clock. There, once again, the problems of the country were exposed, and more concretely, to the Poligono San Pablo. A special mention was made on the unemployment situation. (ECA, 1976e, p. 19)

The law regulating project of the right of assembly, published in the Official State Gazette on March 1, 1976, does not solve the unlawful situation of the proceedings of the neighbour assemblies. Then, the newspaper uses the multiplier effect of the news that supposes to publish any data on permission or denial of authorisation of demonstrations, assemblies, or meetings. Pieces of information such as "A meeting of neighbours in $\mathrm{El}$ Cerezo" (ECA, 1976f, p. 19) often appear in privileged places (cover, back cover, odd pages, local section, or central pages) where the news on the citizen problems define an authentic reclaiming showcase at the time.

This motivates that, although the protest decrease in May-June is three points $(9.09 \%)$ compared to the previous months, the format associations increases (66.6\%) and is the majority, compared to $33.3 \%$ of demonstrations. The newspaper continues to inform, in terms of cases, of the demonstrations conducted by some formal associations, through the neighbours associations, and some informal associations that gathers people living in the same neighbourhood of the city and are mobilised for a common good (ECA, 1976g, central pages) or "The residents' assembly of quarter $\mathrm{C}$ of the Polígono San Pablo" (ECA, 1976h, p. 19).

Citizens begin to be even more aware that, to problems which are apparently unsolvable, solutions must be demanded from the competent authorities. In this way, a dichotomous relationship between the local political power, the Seville City Council, the mayor, and the neighbours as spokesmen for the interests of the quarters is progressively established. One of the clearest examples is the Palmete quarter. In June, a neighbouring protest meeting asks for solutions to the serious problem of water supply and sewerage in the area. The newspaper collects a photograph of the protesters entitled "Palmete insists" accompanying the piece of information "Almost three million in certificates for works in national schools" (ECA, 1976i, p. 19).

\subsection{Protest Rise and Increasing Politicisation}

Sevillians begin to observe the results of the first democratising measures of the first Adolfo Suárez's government from July 1976. During the summer period, the information on protests is reduced to $6.06 \%$, of which $100 \%$ are speeches. Other citizen requirements, such as housing construction, shelter solution and necessary infrastructure in the neighbourhoods (sewerage, access arrangement, lighting, public schools, outpatient clinics, market, street signage, etc.), the lack of which makes the situation of some quarters unsustainable where the vital conditions are deplorable to subhuman extremes, are added to the demands for amnesty and freedom, a fair wage, or the opening of schools.

This also extends to the disagreement with some public works, in the case of the piece of information "Manifesto of La Corta de la Cartuja" (ECA, 1976j, p. 32), in which the promoter board of the Provincial Confederation of Neighbouring Associations and the neighbouring associations in the process of legalisation, after seeing how they are suffering restrictions in the city in the water supply since the beginning of the year, criticise the works of La Corta de la Cartuja and the delay in the construction approval of the El Gergal reservoir.

The protest returns to recover the pulse in the September-October period, obtaining the highest value of the whole period analysed with $18.8 \%$, which is especially demanding, since $100 \%$ of the answer presents the format demonstrations that already have authorisation from which the newspaper provides timely information. In the short news "The Association of family heads requests a demonstration" (ECA, 1976k, p. 39), the San Jerónimo Association of family heads asks the Civil Government permission for a demonstration in which they request a fast regulation of traffic lights in numerous quarter crossings. Three days later, the news "The demonstration of San Jerónimo's neighbours to request traffic lights authorised" (ECA, 1976l, p. 12) is published, where it is specified that signs and posters will not be carried and that "the demonstration will take place despite the news about the City Council having already taken action".

More elements of clear political content are progressively introduced in the texts as seen in the news "More traffic lights!" (ECA, 1976m, left central page), which explains that San Jerónimo's neighbours demand traffic 


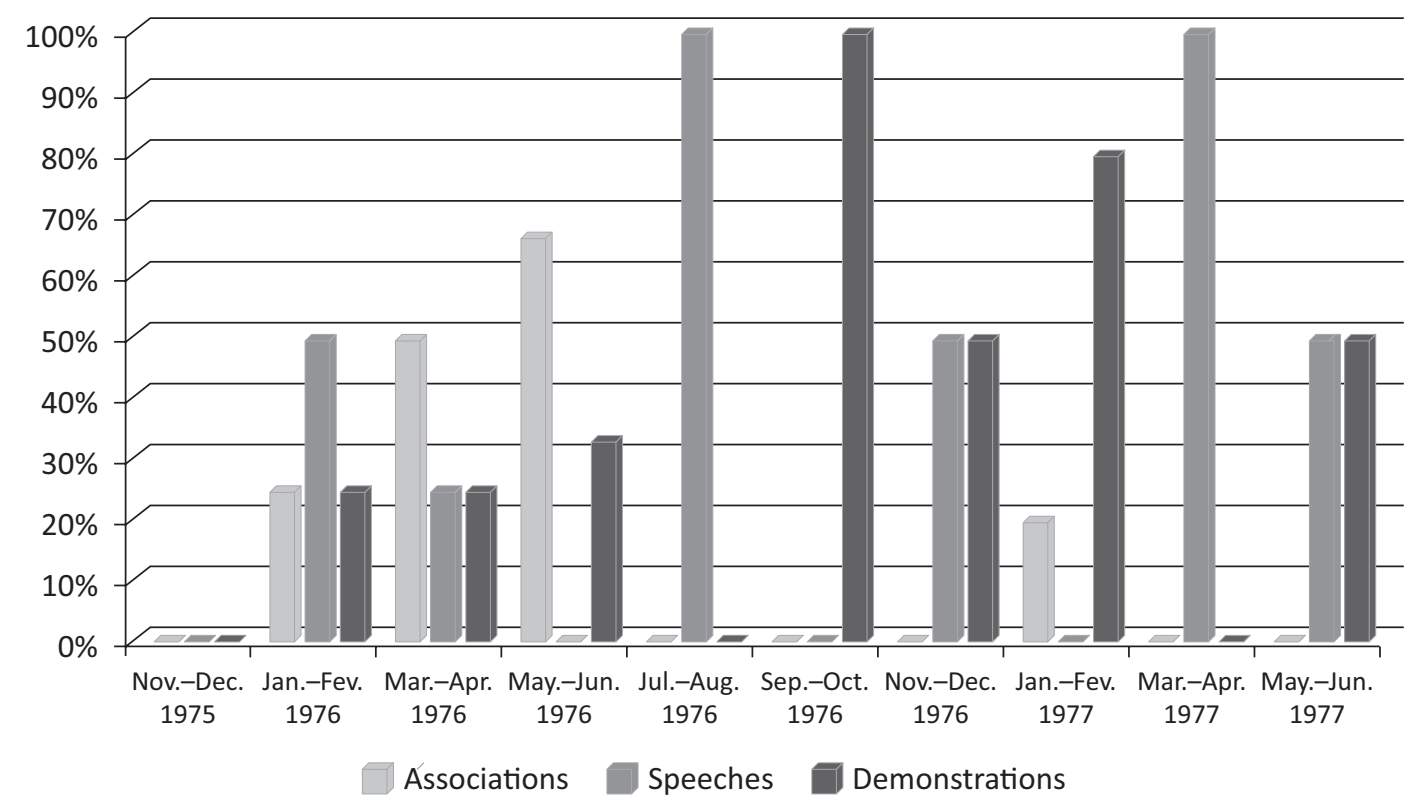

Figure 2. Typology of neighbouring protest in ECA (1975-1977).

lights holding numerous placards with different slogans, including the white and green Andalusian flags, one of which heads the demonstration with the label "The San Jerónimo association requires traffic lights" and that the episode "develops in the most complete normality". In October, the newspaper echoes the acts of protest in the street as expressed by the demonstrations of the Palmete residents in which they ask for a solution to their eternal water and sewer problem. Additionally, the unfulfilled promises of the mayor that are recurring at the end of the year stand out: "Approximately 1,500 people demonstrated in Palmete" (ECA, 1976n, p. 39), "Palmete's residents cut the traffic on the Su Eminencia road again" (ECA, 1976o, p. 17) or "Palmete's neighbours cut the traffic in Su Eminencia for an hour" (ECA, 1976p, p. 39).

The attenuation of the protest in the months of November and December causes it to return to the indexes at the beginning of the year (12.1\%). The speeches reappear and have the same percentage as the demonstrations (50\%), such as the one that collects the news "Demonstration of Palmete's neighbours" (ECA, 1976q, p. 38), where a solution is requested to the issue of the canal which hinders the access of children to a kindergarten.

The speeches gather forthright criticisms towards the authorities: "We sincerely think that the action of the Ministry for Housing-if not the same as the Polígono Aeropuerto-can be positive, although somewhat slow" (ECA, 1976r, p. 11) and take ownership of the neighbouring issues: "Palmete is already in the hands of the Ministry for Housing" (ECA, 1976s, p. 15). The newspaper is not only a spokesperson for citizens' needs, but it also criticises the local government, as proposed in the municipal review of 1976 which reflects the feeling of public discontent in contemplating the perpetuation of the problems in the poorest neighbourhoods, essentially of shelters (ECA, 1976t, central pages).

\subsection{Drift to the Municipal Opposition}

An upturn of the neighbouring protest in the first months of 1977 is noted. January and February are the months with the highest percentage in the texts with the second highest value of the period studied (15.1\%). In this case, $20 \%$ is the format associations, while the pieces of information on demonstrations in many neighbourhoods in Seville increase to $80 \%$ as in the La Oliva quarter which come to shut themselves away in the local community to protest against the negligent attitude of the Municipal Patronage, according to the text "One hundred neighbours were held in the community premises" (ECA, 1977a, p. 31). At another time, expropriation or attachment is the object of the piece of information "Housing and plots will not be expropriated" (ECA, 1977b, p. 11), in which the consequences for the area inhabitants are explained.

The municipal criticism against the mayor is also intensified in pieces of information such as "Protest for the proceedings of the Seville mayor" (ECA, 1977c, left central page), where the newspaper exposes that the respondents are representatives of all neighbouring associations of the seventh and eighth municipal districts because they consider that the mayor must have been contacted by the democratic neighbouring associations to elaborate on the Neighbourhood Emergency Plan.

The Government authorises the registration of the parties in the Register of Political Associations in March. By then, everything is flooded with politics. A month before, one of the promoters of the first neighbouring association in five years, the Unit of the Polígono San Pablo, is interviewed. Among the questions is the political pur- 
pose of the association, whose response contains democratic reminiscences of the socio-political moment:

Apart from the democratic character of the association, we are aware that the social aspect is often intimately related to politics. Any decision between two social and economic approaches is a political decision. Only in this sense can we be considered politicians. (ECA, 1977d, p. 22)

The protest declines in March-April to $9.09 \%$; the speeches capture the $100 \%$ which makes the neighbouring answer more based on the dialogue and less combative in the street. There are news in which Sevillians demand public services and infrastructure improvements in the first person or on behalf of an association. Following this line, the headlines begin to be more striking and direct as "City council, what is given is not removed" (ECA, 1977e, p. 17), words taken from the conversation with some members of the La Corza Association of family heads. At the same time, the citizen as an individual or collective entity becomes a protagonist of the piece of information with headlines such as "Do not want to continue living in La Corchuela" (ECA, 1977f, p. 19), news in which the association of family heads of the quarter describes the situation of the inhabitants of the area.

In the last two months of May-June, the claim drops to $6.06 \%$. Speeches and demonstrations divide up to $50 \%$. Among the speeches we find the piece of information "The residents of El Polvorín require green zones" (ECA, 1977g, right central page), where the main source used is the secretary of the owner's community, and is headed by a photograph of one of the streets of the quarter. The baggage of protest actions in June resulted in the frontal clash with the municipal authority in pieces of information such as "Protesters from La Corchuela did not let the mayor drive his car" (ECA, 1977h, p. 1, right central page), where neighbours raise their voices more as journalistic sources.

\section{Discussion}

The protest of the neighbouring movement in the press during Transition in Seville is a clear example of the citizen dissatisfaction due to multiple urban problems, lack of housing and basic infrastructures. In this way, the newspaper publishes issues related to the conflict and the controversy, altercations, demonstrations, speeches and associations. The strategies used have fundamentally been: timely and repeated information on the holding of assemblies and authorisation of demonstrations; treatment of problems in cases (Palmete and La Corchuela); daily showcase of conflicting news about the world of neighbourhood and urban problems; headlines with direct and controversial language to make the tension states of the neighbours explicit; stories of unlucky encounters with the mayor; the highlights of the continuity of the same problems; usage of photographs with a descriptive function of the social environment and giving evidence of the deficiencies of the most humble quarters, and generalisation of the sources usage as the neighbours and presidents of associations.

We find the accompaniment from the beginning of a clear political content in the texts that increases as Transition advances. Issues related to the neighbouring movement are also newsworthy if they are escorted by an attitude related to democratic change, freedom of association, and requests for amnesty, and replicas in an attempt to promote local debate, enhance the political nuance of neighbouring associations and to establish a set of opposing views in the absence of political parties. The information flow of the neighbouring answer coincides with the political circumstances of the moment, constant in all stages, especially in the first two. The media coverage of the protest of 1976 is managed especially through demonstrations and speeches, although the first are present almost all year which gives an idea of the belligerent attitude within the social mobilisation as a whole.

We observe the awakening of local consciousness (12.12\%) between January and April 1976 with the texts published within the format of level 2 of conflict (speeches and especially associations), which expose small local battles. Only at first, the newspaper shows itself as an external observer (extra level), but when the political factor intervened in the neighbouring demands at the beginning of 1976, it assumes a level of neutral intermediary exposing its claims and serving as a platform (inter level). From the autumn months, when the results of the first democratising measures of Suárez's first government begin to be observed, there is a growth of demand which reaches the highest values of the entire period studied in September and October (18.18\%), being mostly of level 1 , or high level, with high percentages of demonstrations. At a time when anti-Franco political opposition is not legalised, texts dealing with neighbouring issues acquire a greater degree of political content and channel democratising ideas, demonstrating that it does not remain indifferent to political and social reality. The newspaper then reaches an intra level of actor involved when it criticises the local government and is accentuated by giving more strength to the critical voices that come from the neighbours who exercise the municipal opposition in the following year.

The protest resumes to grow in the first months of $1977(15.15 \%)$ with a high increase in demonstrations. As the political parties are legalised and the first democratic elections in June are approaching, the protest decreases until reaching half of the initially achieved (6.06\%). During the spring, the speeches are the main protagonists at a time when dialogue prevails, although demonstrations reappear where the role of the neighbour turns up as an opponent of local political authority convinced that the municipal changes go through democratisation. By then, the decline of published texts on the neighbouring movement coincides with the transfer of objectives and personnel to other groups and especially to the political 
sphere. In this sense, the absence of texts on associations is notorious until the end of the period.

\section{Conclusions}

Throughout the Transition process, the neighbour is represented in the press as a citizen in a local democratic environment, normalising behaviours and patterns of action through protest. The press contributes to make the neighbour, who publicly demands, responds, and struggles on the street, becomes an example for the neighbour who observes him, assumes his action and identifies with him by reading the text published in the newspaper. If the neighbouring associations are conceived as schools of democracy, the press-especially for the involvement of the newspaper studied-contributes to the spreading and amplification of citizen awareness and to educate in democratic functioning from the proximity.

With all of this, we can affirm that, at a time when the local movement in the democratic Transition is being valued, the press becomes an ally of the neighbouring movement when it comes to publicising its struggle, and serves as a platform to give visibility to the democratising culture during Transition in Seville, in which the neighbour also learns to be a citizen. Nonetheless, the analysed newspaper is only an advanced example by its own professional trajectory of struggle for democracy. It would be convenient to conduct studies on other contemporary newspapers to compare to opposite or similar views in order to obtain a more complete global overview.

\section{Conflict of Interests}

The author declares no conflict of interests.

\section{References}

Alonso, N. (2011). The neighbouring movements in Rome during the Italian protest cycle (1968-1976). Segle XX. Revista Catalana D'Història, 4, 57-77.

Althaus, C. (2000). Neighbouring movement and direct democracy in the early 50s. Geschichte im Westen (GiW), 15, 95-114.

Angulo, J. (1978). Municipality, elections and neighbours. For some democratic councils. Madrid: La Torre Edition.

Bardin, L. (1996). Content analysis. Madrid: Akal.

Barrera, C. (1995a). Journalism and Francoism. From censorship to opening. Pamplona: Eunsa.

Barrera, C. (1995b). Without gags. Twenty years of press in democracy. Madrid: Temas de Hoy.

Bordetas, I. (2014). Studies on neighbouring movement: A challenge still for historiography. Franquisme \& Transició, 2, 281-295.

Borja, J. (1986). For some democratic municipalities. Ten years of political reflection and citizen movement. Madrid: Institute of Local Administration Studies.
Borrat, H. (1989). The newspaper, political actor. Barcelona: Gustavo Gili.

Bultmann, I., Hellmann, M., Maschkat, K., \& Rojas, J. (Eds.). (1995). Democracy without social movement? Trade unions, neighbouring organizations and women's movements in Chile and Mexico. Caracas: Editorial Nueva Sociedad.

Carrasco, L. (2011). The role of communication in the processes of citizen participation at the local level: The case of the district of Barranco. Lima: Pontifical Catholic University of Peru, Faculty of Communication Sciences and Arts.

Castells, M. (1986). The city and the masses. Sociology of urban social movements. Madrid: Alianza Editorial.

Contreras, J. (2012). The neighbouring movement in Andalusia during late Francoism and the process of political change (1968-1986): Exceptional or outstanding actor? Gerónimo de Uztariz, 28/29, 95-122.

Contreras, J. (2013). Legitimacy is gained on the street. The disruptive actions of the Andalusian neighbouring movement (1968-1987). Revista de Historia Actual, 11, 91-103.

De Pablos, M. (1981). The press. Who counts Seville? Seville: Grupo Andaluz Ediciones Repiso-Lorenzo.

El Correo de Andalucía. (1976a, January 2). The running construction work in the quarter La Tercia is considered insufficient. El Correo de Andalucía.

El Correo de Andalucía. (1976b, January 8). Residents of five neighbourhoods request amnesty. El Correo de Andalucía, p. 20.

El Correo de Andalucía. (1976c, February 11). Demonstration of neighbours with lit candles. El Correo de Andalucía, p. 20.

El Correo de Andalucía. (1976d, April 4). Palmete's residents insist. El Correo de Andalucía, p. 15.

El Correo de Andalucía. (1976e, March 25). Peaceful demonstration in the districts $A$ and $B$ of the Polígono San Pablo. El Correo de Andalucía, p. 19.

El Correo de Andalucía. (1976f, March 10). A meeting of neighbours in El Cerezo. El Correo de Andalucía, p. 19.

El Correo de Andalucía. (1976g, May 26). A neighbour assembly could not be held last night. El Correo de Andalucía.

El Correo de Andalucía. (1976h, June 2). The residents' assembly of quarter $\mathrm{C}$ of the Polígono San Pablo. El Correo de Andalucía, p. 19.

El Correo de Andalucía. (1976i, June 26). Palmete insists. El Correo de Andalucía, p. 19.

El Correo de Andalucía. (1976j, July 14). Manifesto of La Corta de la Cartuja. El Correo de Andalucía, p. 32.

El Correo de Andalucía. (1976k, September 12). The Association of family heads requests a demonstration. El Correo de Andalucía, p. 39.

El Correo de Andalucía. (1976I, September 15). The demonstration of San Jerónimo's neighbours to request traffic lights authorised. El Correo de Andalucía, p. 12.

El Correo de Andalucía. (1976m, September 19). More 
traffic lights! El Correo de Andalucía.

El Correo de Andalucía. (1976n, October 10). Approximately 1,500 people demonstrated in Palmete. El Correo de Andalucía, p. 39.

El Correo de Andalucía. (1976o, October 17). Palmete's residents cut the traffic on the Su Eminencia road again. El Correo de Andalucía, p. 17.

El Correo de Andalucía. (1976p, October 24). Palmete's neighbours cut the traffic in Su Eminencia for an hour. El Correo de Andalucía, p. 39.

El Correo de Andalucía. (1976q, December 12). Demonstration of Palmete's neighbours. El Correo de Andalucía, p. 38.

El Correo de Andalucía. (1976r, December 17). The secret agreements with the Ministry for Housing on Palmete. El Correo de Andalucía, p. 11.

El Correo de Andalucía. (1976s, December 21). Palmete is already in the hands of the Ministry for Housing. El Correo de Andalucía, p. 15.

El Correo de Andalucía. (1976t, December 29). Review to the municipal year 1976. El Correo de Andalucía.

El Correo de Andalucía. (1977a, February 23). One hundred neighbours were held in the community premises. El Correo de Andalucía, p. 31.

El Correo de Andalucía. (1977b, February 5). Housing and plots will not be expropriated. El Correo de Andalucía, p. 11.

El Correo de Andalucía. (1977c, February 13). Protest for the proceedings of the Seville mayor. El Correo de Andalucía.

El Correo de Andalucía. (1977d, February 6). A neighbouring association is legalised in Seville. El Correo de Andalucía, p. 22.

El Correo de Andalucía. (1977e, March 5). City council, what is given is not removed. El Correo de Andalucia, p. 17.

El Correo de Andalucía. (1977f, April 29). Do not want to continue living in La Corchuela. El Correo de Andalucía, p. 19.

El Correo de Andalucía. (1977g, May 4). The residents of El Polvorín require green zones. El Correo de Andalucía.

El Correo de Andalucía. (1977h, June 9). Protesters from La Corchuela did not let the mayor drive his car. El Correo de Andalucía, p. 1.

Escaleras, J., \& Ruiz, E. (2006). Neighbouring associations in Andalusian medium cities. Revista de Estudios Andaluces, 26, 37-66.

Fernandes, T. (2015). Rethinking pathways to democracy: Civil society in Portugal and Spain, 1960s-2000s. Democratization, 22(6), 1074-1104. doi:10.1080/ 13510347.2014.901966

Ferrer, C. (2014). Everyday fighters. Anti-Francoism, political change and the construction of democracy in the Montsià (1972-1979). Lleida: University of Lleida editions.

Frutos, M. (2002). The participation of the popular urban movement in the process of political change in the Federal District (1986-1997) (Doctoral dissertation). Latin American Faculty of Social Sciences, Mexico City, Mexico.

Fuentes, J. F., \& Fernández, J. (1998). History of Spanish journalism: Press, politics and public opinion in contemporary Spain. Madrid: Síntesis.

Gail, A. (1979). "Vox populi": The development of neighbouring associations in Spain. Papers, Revista de Sociología, 11, 169-183. doi:10.5565/rev/ papers/v11n0.1164

García, L. (1981). Theory of Transition: An analysis of the Spanish model, 1973-1978. Madrid: National Publisher.

Giner, S., \& Sevilla, E. (1980). From despotism to parliamentarianism: Class domination and political order in the Spanish state. In R. Scase (Ed.), The state in Western Europe (pp. 197-229). London: Croom Helm.

Gómez, M., \& González, M. (Eds.). (2000). Contemporary history of Andalusia. New contents for the study. Granada: The Education and Science Ministry from the Regional Government in Andalusia.

Gómez Bahillo, C. (2006). Neighbouring organizations and citizen participation. The case of the city of Zaragoza. Rio. Revista Internacional de Organizaciones. doi:10.17345/rio0.\%25p

Gomis, L. (1987). The media "mediate". The political role of the press. Barcelona: Mitre.

Gonzalo, C. (2015). The news is in the quarters. Media and neighbouring movement from Valladolid in the Transition. Revista Internacional de Historia de la Comunicación, 1(4), 131-152.

Iglesias, F. (1980). History of a journalistic company: Prensa Española, editor of $A B C$ and Blanco y Negro (1891-1978). Madrid: Prensa Española.

Institut D’Anàlisi i Social Politiques Pùbliques \& Fundaciò Francesc Ferrer I Guàrdia. (2000). New employment opportunities in the third sector. An economic, labour and organisational approach of the third sector in Spain. Barcelona: Fundaciò Francesc Ferrer i Guàrdia.

Lander, E. (2006). Neo-liberalism, civil society and democracy. Essays on Latin America and Venezuela. Caracas: Central University of Venezuela and Council of Scientific and Humanistic Development.

Lowe, S. (1986). Urban social movements: The city after Castells. London: MacMillan.

Luna, I. (2003). Media and democracy: Reality, civic culture and legal and political responses. Derecho Comparado de la Información, 1, 21-39.

Martínez i Muntada, R. (2008). The neighbouring movement during late Francoism: Collective action and worker culture. Proposals and interpretation issues. In M. E. Nicolás \& C. González (Eds.), Yesterdays are under discussion. Key issues of contemporary history today (pp. 2333-2347). Murcia: Publication Service of the University of Murcia.

Méndez-Muros, S. (2013). The media protest as a mirror of the civil reappearance in the democratic Transition of Spain. Anduli, 12, 67-90. 
Montero, M., Rodríguez, J., \& García, C. (2008). The role of the media in building a political community. The press in the transition to democracy in Spain. Palabra Clave, 2, 293-309.

Musil, F. (2013). Social and political victims become the founders of a new democratic civil society under dictatorial rule. Revista Convergência Crítica, 3, 10-25.

Oraisón, M. (2011). On the relationship state-civil society: Citizen participation. The case of the Neighbouring Commissions of the city of Corrientes, Argentina [Special issue]. Nómadas. Revista Crítica de Ciencias Sociales y Jurídicas. doi:10.5209/ rev_NOMA.2011.37947

Ortega, M. T. (2004). Workers and neighbours during late Francoism and political transition (1966-1977): A joint "struggle" for the same purpose. Historia Contemporánea, 16, 351-369.

Pérez Díaz, V. (1987). The civil society return: Social responses to the political transition, the economic crisis and the cultural changes of Spain 1975-1985. Madrid: Institute for Economic Studies.

Pérez Díaz, V. (1996). Spain been tested (1976-1996). Madrid: Alianza Editorial.

Pérez Quintana, V., \& Sánchez, P. (Eds.). (2008). Citizen's report and neighbouring movement. Madrid 19682008. Madrid: Los Libros de la Catarata.

Pérez Vilariño, J. (1982). The newspapers faced with the autonomies. Madrid: Akal.

Ramos Pinto, P. (2005, April). The Lisbon Commune: The social roots of political movements in the Portuguese Revolution 1974-6. Paper presented at ECPR Joint Sessions of Workshops, Workshop 19 "Local Participation in Different Contexts", Granada, Spain.

Ramos Rollón, M. L. (1995). From protests to proposals. Identity, action and political relevance of the neighbouring movement in Venezuela. Caracas: University of Salamanca, Interuniversity Institute of Studies of Ibero-America and Portugal.

Safa, P. (1998). Neighbours and neighbourhoods in Mexico City: A study on the construction of neighbouring identities in Coyoacán, D. F. Mexico D. F: Centre for Research and Higher Studies in Social Anthropology, Universidad Autónoma Metropolitana-Iztapalapa.

Salgado, J. M. (2014). The pluralism of the neighbouring movement in the Nou Barris District (Barcelona) during late Francoism. Social and Education History, 3(3), 271-295.

Sánchez, P. (2011). Radicalism without representations: On the character of social movements in the Spanish transition to democracy. In D. Muro \& G. Alonso (Eds.), The politics and memory of democratic transition: The Spanish model (pp. 96-110). New York, NY: Routledge.

Serrano, J., \& Sempere, D. (Eds.). (1999). The youthful participation in Spain. Barcelona: Fundació Francesc Ferrer i Guàrdia.

Sinova, J. (1989). The difficult evolution of the non-state press. In J. Timoteo \& C. Aguilera (Eds.), History of the media in Spain. Journalism, image and publicity (1900-1990) (pp. 262-272). Barcelona: Ariel Comunicación.

Threlfall, M. (2008). Reassessing the role of civil society organizations in transition to democracy in Spain. Democratization, 15(5), 930-951. doi:10.1080/ 13510340802362521

Tusell, J. (1989). The Spain of Franco. Power, opposition and foreign policy during the Franco's regime. Madrid: Historia 16.

Vilà, G. (2016). From residents to citizens: The emergence of neighbouring movements in Spain. In N. Gallent \& D. Ciaffi (Eds.), Community action and planning: Contexts, drivers and outcomes (pp. 59-76). Bristol: Policy Press.

Zugasti, R. (2007). The Spanish transitional press as the arena of political support for Juan Carlos I: The example of dynastical legitimacy of monarchy. Palabra Clave, 1, 60-70.

Zugasti, R. (2008). The role of the press in the construction of the Spanish democracy: From Franco's death to the 1978 Constitution. Confines, 4/7, 53-68.

\section{About the Author}

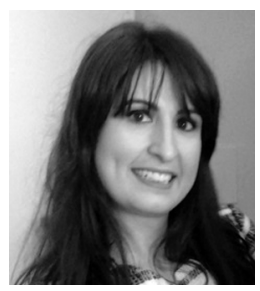

Sandra Méndez-Muros (PhD) is a Lecturer with the Department of Journalism II of the University of Seville, Spain, where she has taught the subject of History of Spanish Journalism. She has participated in two research projects on Historical Memory and has made research stays at the Nova University of Lisbon and the University of Algarve, Portugal. Her publications in books, journals, and conference proceedings focus on research on civil society during the Spanish democratic Transition in the local press. 